\title{
UPPER AND LOWER MOTOR NEURON LESIONS IN THE UPPER EXTREMITY MUSCLES OF TETRAPLEGICS ${ }^{1}$
}

\author{
By P. H. Peckham, J. T. Mortimer and E. B. Marsolais* \\ Engineering Design Center and Department of Biomedical Engineering, ${ }^{\star D e p a r t m e n t}$ of \\ Orthopaedic Surgery, Case Western Reserve University, Cleveland, Ohio 44106
}

VIABILITY of the lower motor neuron is imperative if paralysed muscles are to be electrically activated for functional use. Recently, functional use of the hand has been obtained through excitation of paralysed forearm muscles (Peckham et al., 1973; Mortimer \& Peckham, I973). These advantages were achieved with subjects whose stimulated muscles had little or no involvement of the peripheral nerve, i.e. an upper motor neuron lesion. In general, however, one could expect some involvement of the lower motor neuron to be present because trauma resulting from the spinal cord injury often extends one or more segments rostral and caudal to the site of damage (Guttmann, I973) and may involve the cell bodies of peripheral nerves which exit the spinal cord near the level of injury or the spinal nerves themselves (Haymaker, 1953).

The present study was designed to investigate the muscles of a small population of high level spinal cord injury patients in order to determine those that potentially could be used for functional electrical stimulation. Specifically, the objective of this study was to evaluate the nature of the muscle innervation of the forearm and hand muscles of quadriplegic patients.

\section{Methods}

Subjects. These studies were carried out on 24 tetraplegic patients. The post-injury period ranged from 3 months to 18 years, most being tested less than I year post-injury. Table I lists the subjects who were examined in this study. Subjects were classified according to their level of injury as given in their history. This group of patients represents virtually all $\mathrm{C}_{5}$ tetraplegics and some $\mathrm{C}_{4}$ and C6 quadriplegics who were admitted to the Spinal Cord Injury Ward at Highland View Hospital during a 3 year period (1972-74).

Procedure. All of the muscles that were tested were totally paralysed. Muscles were examined using three techniques: reflex activity, electrical stimulation and electromyography. In the first test, a mechanical impulse (tap) was applied to the tendon to determine the existence of monosynaptic reflex activity, indicative that the lower motor neurons were at least partially intact. This test was used primarily as an initial screening procedure for other studies involving electrically induced exercise (Peckham et al., 1975).

The second test for intactness of the lower motor neuron involved the application of a supramaximal stimulus to each major nerve trunk at or above the elbow. The stimulus was a monophasic, rectangular, current regulated ("constant current') waveform with a pulse width of less than $500 \mu \mathrm{sec}$, frequency of $20 \mathrm{~Hz}$, and stimulus amplitude adjusted to a level which was greater than needed to excite all fibres of the nerve trunk. In most cases this was supplemented by stimulation of the muscle at its motor point. This enabled the examiner, both by

1 This research was supported by NIH-NINDS Contract No. NoI-NS-2-23I4. 
observation and palpitation, to identify the muscles which were activated by the stimulus. A muscle which could be excited in such a manner and that the subject could not contract voluntarily was judged to have an upper motor neuron lesion (UMNL) with some or all of the lower motor neurons intact. Strength-duration examination often augmented the previous test by measuring the threshold response to an electrical stimulus applied to the motor point. A muscle with a

\section{TABLE I}

Patients examined for upper and lower motor neuron lesions

\begin{tabular}{|c|c|c|c|c|c|}
\hline $\begin{array}{l}\text { Subject } \\
\text { G.M. }\end{array}$ & $\begin{array}{l}\text { Motor } \\
\text { level } \\
\mathrm{C}_{4}\end{array}$ & $\begin{array}{l}\text { Age } \\
\text { I6 }\end{array}$ & $\begin{array}{c}\text { Type } \\
\text { fracture-dislocation }\end{array}$ & $\begin{array}{l}\text { Level } \\
\mathrm{C}_{4}, \mathrm{C}_{5}\end{array}$ & $\begin{array}{l}\text { Time post-injury } \\
\text { when examined } \\
\text { I I months }\end{array}$ \\
\hline B. Z. & $\mathrm{C}_{4}$ & I4 & $\begin{array}{l}\text { dislocation } \\
\text { fracture }\end{array}$ & $\left.\mathrm{C}_{3}, \mathrm{C}_{5}\right\}$ & 4 months \\
\hline D. D. & $\mathrm{C}_{4}$ & 19 & fracture & $\mathrm{C}_{3}, \mathrm{C}_{4}$ & 5 months \\
\hline J. L.* & $\begin{array}{c}\mathrm{C}_{4} \text { Right } \\
\mathrm{C}_{5} \text { Left }\end{array}$ & 18 & fracture-dislocation & $\mathrm{C}_{5}, \mathrm{C} 6, \mathrm{C}_{7}$ & 6 months \\
\hline H. D. * & $\mathrm{C}_{5}$ & 20 & fracture-dislocation & $\mathrm{C}_{4}, \mathrm{C}_{5}$ & 9 months \\
\hline G. K.* & $\mathrm{C}_{5}$ & 49 & fracture & $\mathrm{C}_{4}$ & 4 months \\
\hline D. D.* & $\mathrm{C}_{5}$ & 37 & fracture-dislocation & $\mathrm{C}_{4}, \mathrm{C}_{5}$ & 8 years \\
\hline F. C.* & $\mathrm{C}_{5}$ & $2 \mathrm{I}$ & fracture-dislocation & $\mathrm{C} 5, \mathrm{C} 6$ & $3 \frac{1}{2}$ months \\
\hline G. R.` & $\mathrm{C}_{5}$ & I6 & fracture & $\mathrm{C}_{5}$ & 6 months \\
\hline W. R.` & $\mathrm{C}_{5}$ & I9 & fracture dislocation & $\mathrm{C}_{3}, \mathrm{C}_{4}, \mathrm{C}_{5}$ & $3 \frac{1}{2}$ months \\
\hline W. C.` & $\mathrm{C}_{5}$ & 25 & fracture & $\mathrm{C}_{5}$ & 9 months \\
\hline 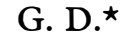 & $\mathrm{C}_{5}$ & I7 & fracture & $\mathrm{C}_{5}, \mathrm{C} 6$ & 7 months \\
\hline M. S.* & $\mathrm{C}_{5}$ & I6 & fracture-dislocation & $\mathrm{C}_{5}$ & $3 \frac{1}{2}$ months \\
\hline F. S.` & $\mathrm{C}_{5}$ & 19 & fracture & $\mathrm{C}_{5}, \mathrm{C} 6$ & I4 months \\
\hline R. M.` & $\mathrm{C}_{5}$ & 20 & fracture & C6 & 4 months \\
\hline C. V. & C5 & I9 & subluxation fracture & $\mathrm{C}_{4}, \mathrm{C}_{5}$ & 5 months \\
\hline P. B. & $\mathrm{C}_{5}$ & 22 & fracture-dislocation & $\mathrm{C} 5, \mathrm{C} 6$ & 4 months \\
\hline I. B. & $\mathrm{C}_{5}$ & 28 & fracture & $\mathrm{C} 5, \mathrm{C} 6$ & $5 \frac{1}{2}$ months \\
\hline R. F. & $\mathrm{C}_{5}$ & I 8 & dislocation & $\mathrm{C}_{5}, \mathrm{C} 6$ & 9 months \\
\hline P. S. & $\mathrm{C}_{5}$ & I6 & fracture-dislocation & $\mathrm{C}_{5}, \mathrm{C} 6$ & 5 months \\
\hline T. P & C5 & 30 & fracture & $\mathrm{C}_{5}$ & $2 \frac{1}{2}$ years \\
\hline M. F. & $\mathrm{C} 6$ & 20 & fracture & $\mathrm{C} 5$ & 3 months \\
\hline 1 & C6 & I 8 & fracture-dislocation & $\mathrm{C} 6, \mathrm{C}_{7}$ & 5 months \\
\hline & C6 & 22 & fracture-dislocation & C6 & Io months \\
\hline
\end{tabular}

* Subjects who participated in a programme involving chronic electrical stimulation (Peckham et al., 1975).

chronaxie of less than I msec and a break in the strength-duration curve was judged to have a mixed upper and lower neuron lesion. A muscle with chronaxie of greater than I msec with no break in the strength-duration curve was judged to have a lower motor neuron lesion.

Electromyography was used occasionally to test for denervation activity. However, for the vast majority of muscles, this procedure was not used because many of the subjects were examined too long after the injury for denervation activity to be pronounced and secondly because this technique measured only a small sample of the muscle which might or might not contain denervated fibres, and therefore only by chance could detect denervation.

The nerve and motor point stimulation tests were performed on all muscles. Less frequently strength-duration testing was performed and only occasionally was 
electromyography employed. In choosing the muscles to be evaluated, emphasis was placed on those muscles that were felt to be most useful for hand-forearm orthoses utilising electrical stimulation. The muscles evaluated included Flexor Digitorum Superficialis (FDS), Flexor Digitorum Profundus (FDP), Extensor Digitorum Communis (EDC), Extensor Indicus (EI), Extensor Carpi Radialis Longus and Brevis (ECRL/ECRB), Opponens Pollicus (OP), Flexor Pollicus Longus (FPL).

The major emphasis on these studies was to determine whether the lower motor neurons remained intact to the forearm finger flexor (FDS/FDP) and extensor $(\mathrm{EDC} / \mathrm{EI})$ muscles. In this test, muscles that responded to electrical stimulation were separated further into two categories depending upon the strength of the electrically induced contraction which was evaluated with a manual muscle test. Those with weak force were Grade 2 and 3 (poor to fair), meaning that the muscle produced sufficient force to overcome gravity through its full range of motion or less. Muscles with moderate force were Grade 4 (good) and removed against resistance throughout their full range of motion.

\section{Results}

The results of this study of the finger flexor muscles (FDS/FDP) are shown in Table II. Of a total of 55 muscles that were examined, only four muscles, all in one subject (P. B.) sustained a complete lower motor neuron lesion. The vast majority of the muscles had a sufficient number of the lower motor neurons intact

TABLE II

Type of lesion in the finger flexor muscles (FDS, FDP)

\begin{tabular}{|c|c|c|c|c|}
\hline & \multicolumn{4}{|c|}{ Mixed or UMNL } \\
\hline Motor & Total & Weak & Moderate & Total \\
\hline level & LMNL & force & force & examined \\
\hline $\mathrm{C}_{4}$ & 0 & 0 & 6 & 6 \\
\hline $\mathrm{C} 5$ & 4 & I & 37 & 42 \\
\hline C6 & 0 & 0 & 7 & 7 \\
\hline
\end{tabular}

TABLE III

Type of lesion in the finger extensor muscles (EDC, EI)

$\begin{array}{ccccc}\begin{array}{c}\text { Motor } \\ \text { level }\end{array} & \begin{array}{c}\text { Total } \\ \text { LMNL }\end{array} & \begin{array}{c}\text { Mixed or UMNL } \\ \text { Weak }\end{array} & \begin{array}{c}\text { Moderate } \\ \text { force }\end{array} & \begin{array}{c}\text { Torce } \\ \text { examined }\end{array} \\ \text { C4 } & 0 & 0 & 3 & 3 \\ \text { C5 } & 6 & \text { I } & \text { I8 } & 25 \\ \text { C6 } & \text { I } & \text { I } & 4 & 6\end{array}$

to provide movement against resistance through their full range of motion. However, the forces generated were generally less than that necessary for functional usage (Peckham et al., I975).

The results of this study on the finger extensor muscles (EDC/EI) are shown in Table III. In general, the results are similar to those with the finger flexor muscles. Of 34 muscles examined, seven were completely denervated (four in subject P. B.), and two generated only a weak force with maximal stimulation. 
Table IV shows the results that were obtained from examination of all subjects. The absence of a response indicates that the muscle was not tested. The vast majority of muscles that were tested sustained a total upper motor neuron lesion or a mixed upper/lower motor neuron lesion and hence would be viable for functional

TABLE IV

Upper and lower motor neuron lesions in quadriplegic patients

Subject Motor FDS FDP EDC EI ECRL/B OP FCU Triceps FCR

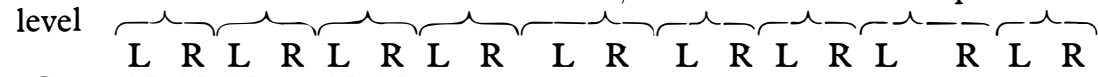

G. M. $\mathrm{C}_{4} \quad \mathrm{U}$ U U $-\mathrm{U}$ U

B. Z. $\mathrm{C}_{4} \mathrm{U} \mathrm{U}$

J. L. $\quad \mathrm{C} 4-\mathrm{U}$

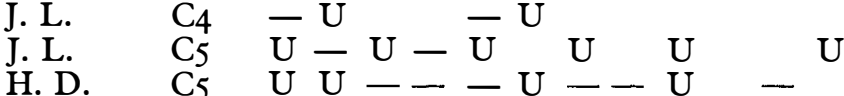

G. K. C5 U $-\frac{\mathrm{U}}{\mathrm{U}}-\overline{\mathrm{U}}-\mathrm{U}$

D. D. C5 U- U U

F. C. C5 U U U

G. R. C5 U U U U L L

W. R. C5 U U $-U U$ U

W. C. C5 U U U

G. D. $\quad \mathrm{C}_{5} \quad \mathrm{U} M \quad \mathrm{U} M$

M. S. C5 U U U

F. S. C5 U U U U U

R. M. C5 U U U U U U

C. V. C5 U U

P. B. $\quad \mathrm{C}_{5} \mathrm{~L} \quad \mathrm{~L}$

J. B. C5 U U

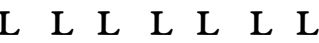

$\mathrm{U}-$

$-\mathrm{U}-$

$\begin{array}{llllll}U & U & U & U & U\end{array}$

R. F. C5 U U

J. P. C5 U U

P.S. C5 U U

M. F. C6 U U

J. D. C6 U U

U U U U

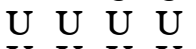

U U U U

L U

B. I. C6 U U U U M

$\begin{array}{llll}U & U & U \\ U\end{array}$

L L

usage when electrically excited. Muscles that generally were included in this group, in addition to the finger flexor and extensor muscles previously discussed are Extensor Carpi Radialis, Opponens Pollicus, Flexor Pollicus Longus, and Flexor Carpi Ulnaris. The Flexor Carpi Radialis, which is important in the balance of the wrist, was an exception. In five of the $C_{5}$ subjects that were tested for this muscle, seven of the ten muscles were found to be denervated.

\section{Discussion}

The results of this study have shown that the lower motor neuron is intact in the great majority of the forearm muscles tested in 24 tetraplegic subjects. Particular attention was directed toward evaluation of the Flexor Digitorum Superficialis and Profundus and the Extensor Digitorum and Extensor Indicus muscles. These muscles are particularly important in the $\mathrm{C}_{5}$ tetraplegic because they provide the primary means for eliciting grasp and release movements through electrically induced muscle contraction. In these subjects, the lower motor neuron was totally or partially intact in $9 \mathrm{I}$ per cent of the finger flexors and 78 per 
cent of the finger extensor muscles which were tested. If subject P. B. is excluded, these percentages rise to I00 per cent for the flexors and 95 per cent for the finger extensors. Exclusion of P. B. from the following discussion appears reasonable, since his accident was particularly traumatic and the resulting paralysis indicated by this study was unlike that of any of the 23 other subjects who were examined.

The amount of involvement of the lower motor neuron is related to the level of injury and the segment of the spinal cord from which the particular muscle received its innervation. The segmental innervation of skeletal muscles is well described (Haymaker, 1956). In keeping with this distribution, $\mathrm{C}_{4}$ subjects had little or no involvement of the finger flexor muscles. (Only three finger extensor muscles in two subjects were tested.) The $\mathrm{C}_{5}$ subjects generally showed the presence of an intact lower motor neuron of the finger flexor muscles but more involvement of the finger extensor muscles which receive their innervation from lower in the cord. Additional muscles which receive innervation from lower level appear to be more involved (e.g., ECR and FRC), although a systematic investigation was not undertaken to demonstrate this observation conclusively. Subjects who sustained an injury at C6 were even more likely to have involvement of the finger extensor muscles (one of six), but finger flexor muscle involvement was similar to that of the $\mathrm{C}_{5}$ group. Thus, it appears that the closer the site of injury is to the level at which the muscle receives its innervation, the greater the chances are of sustaining damage to the lower motor neuron. Subsequently, these muscles would be excitable only by direct stimulation rather than indirect (nerve) stimulation and would not be available for functional usage by present techniques of activation.

The results of this study contradict those previously reported by Doerr and Long (1969). These investigators found a lower motor neuron lesion in the flexor digitorum muscles in each of the three $\mathrm{C}_{4}$ subjects and in one of two muscles in two C6 subjects. No $\mathrm{C}_{5}$ subjects were tested for this muscle. In contrast, this study showed a total motor neuron lesion in only four of 55 finger flexor muscles that were tested. Similar to the results of the present study, Doerr and Long found that six of I I extensor digitorum muscles of four $\mathrm{C}_{4}$, one $\mathrm{C}_{5}$, and two $\mathrm{C} 6$ subjects had a mixed or upper motor neuron lesion. Thus, the results obtained from the finger extensor muscles in the present study are consistent with those found by Doerr and Long but disagree with those found for the finger flexor group. Some of this discrepancy may be due to the differences in the subjects in each population. However, equally important was the technique these investigators used to specify whether a muscle had a LMNL. Although their technique appears rigorous, some error appears to be present in its application, since two muscles stated to have some voluntary activity were judged to be denervated. The results obtained by Doerr and Long with the finger flexor muscles would not be expected based on the level from which those muscles receive their innervation.

The results of Doerr and Long show a possible limitation to the use of functional electrical stimulation in the $\mathrm{C}_{4}$ subject. In three of four $\mathrm{C}_{4}$ subjects examined, lower motor neuron involvement was demonstrated in the biceps muscle. This was confirmed in one of the $\mathrm{C}_{4}$ subjects examined in the present study. Similar results would be expected for other muscles involved in shoulder movement. Thus, in complex systems for achieving elbow flexion and shoulder stability in $\mathrm{C}_{4}$ subjects, an alternative power source to the stimulated muscle may be necessary. The forearm finger flexor and extensor muscles of these subjects appear, in general, to have mixed or total UMNL, and could be functionally excited. 
Most of the subjects evaluated in this study were evaluated within the Ist year post-injury. However, three subjects were evaluated initially at greater than I year post-injury, and four subjects were retested at greater than I year postinjury. The response of the muscles of these subjects was not qualitatively different from those tested within the Ist year. This suggests that the muscles paralysed for an extended period of time and having the lower neuron intact may remain electrically excitable.

The presence of an intact lower motor neuron does not guarantee that the muscle is suitable for functional usage. Rather, one can be certain that such a muscle generally will produce insufficient force and fatigue too rapidly to be used as the prime mover. In related work, it has been demonstrated that such muscles which have atrophied from disuse but retain an intact lower motor neuron can be strengthened to functional levels of contraction through a programme of exercise induced by chronic electrical stimualtion (Peckham et al., 1976). Exercised muscles when electrically activated are then available for functional use. At present, systems utilising electrical stimulation to provide functional movement are being evaluated in clinical and home usage by three $\mathrm{C}_{5}$ quadriplegic patients.

\section{SUMMARY}

Paralysed upper extremity muscles of 24 tetraplegic patients were examined to determine whether their lower motor neuron was intact. Primary emphasis was placed on the forearm finger flexor muscles (Flexor Digitorum Superficialis and Flexor Digitorum Profundus) and finger extensor muscles (Extensor Digitorum Communis and Extensor Indicis). It was found that the vast majority of these muscles in $\mathrm{C}_{4}, \mathrm{C}_{5}$ and $\mathrm{C} 6$ subjects retained some or all of their lower motor neurons intact.

In $\mathrm{C}_{5}$ subjects, examination was performed on additional muscles that were potentially most useful in an orthosis utilising functional stimulation. Similar to the results of the finger flexor and extensor muscles, the muscles of the wrist and thumb generally had the lower motor neuron at least partially intact. A muscle that often was an exception was M. Flexor Carpi Radialis.

These studies indicate that most of the forearm muscles of the upper extremity in high level spinal cord injury patients which are paralysed have the lower motor neuron totally or partially intact. With electrically induced exercise, such muscles are strengthened to functional levels of contraction. Subsequent electrical activation enables the quadriplegic patients to use the muscle functionally.

\section{RÉSUMÉ}

On a étudié les muscles supérieurs paralysés de l'extrémité de vingt quatre patients paralysés pour déterminer que les neurones moteures inferieures soient intactes. Un examen était fait sur les muscles qui avaient un potentiel le plus utile dans une action utilisante un stimulus fonctionel. On a mis l'emphase sur les muscles du doigt de l'avant bras flechisseurs et extenseurs. Les études ont indiquées que la plupart des muscles paralysés de l'extrémité dans les patients avec une blessure supérieure de la meolle épinière ont les neurones moteures complétement ou partiellement intactes. Activation électrique suivante peut permettre d'user fonctionellement des muscles du patient paralysé.

\section{ZUSAMMERFASSUNG}

In vierundzwanzig tetraplegischen Patienten wurden die gelähmten oberen Extremitäten untersucht, um festzustellen, ob das zweite motorische Neuron intakt war. Die 
Untersuchung wurde en den Muskeln vorgenommen, die den potentiell grössten Nutzen versprechen, wenn ein Hilfsapparat mit funktioneller Stimulation benutzt wird. Besonderer Wert wurde dabei auf die Fingerbeuger-und strecker der Unterarmmuskeln gelegt. Die Untersuchungen zeigten, dass bei Patienten mit hoher Verletzung des Rückenmarks die meisten gelähmten Muskeln der oberen Extremitäten ein vollständig oder teilweise intaktes zweites motorisches Neuron besitzen. Elektrische Aktivierung könnte es den tetraplegischen Patienten ermöglichen, diese Muskeln funktionell zu benutzen.

\section{REFERENCES}

DoERR, G. M. \& LONG, C. (1969). Electrical response and electromyograms of upper extremity muscles in quadriplegics. Orthotics and Prosthetics, 23:I, 20. (I973)

GutTmanN, L. (1973). Spinal Cord Injuries. Oxford: Blackwell Scientific Publications.

Haymaker, W. \& Woodhall, B. (I953). Peripheral Nerve Injuries: Principles of Diagnosis. Philadelphia: W. B. Saunders, Company.

Mortimer, J. T. \& PeCKham, P. H. (I973). Intramuscular Electrical Stimulation. Neural Organization and its Relevance to Prosthetics, ed. W. S. Fields. Miami: Symposia Specialists, p. I3I.

Peckham, P. H., Marsolais, E. B. \& Mortimer, J. T. (I973). Intramuscular Stimulation: Applications to Upper Extremity Orthotics. Presented at the 4th Annual MeetingBiomedical Engineering Society, Paper 5.4. Los Angeles: California.

Peckham, P. H., Mortimer, J. T. \& Marsolais, E. B. (I976). Alteration in the force and fatigability of skeletal muscle in quadriplegic humans following exercise induced by chronic electrical stimulation. Clinical Orthopedics and Related Research, 114, 326. 